\title{
Ruminant Abortus Vakalarında Coxiella burnetii'nin Real Time PCR ile
}

\section{Araştırılması}

\author{
Sevil ERDENLiĞ GÜRBiLEK ${ }^{1}$, Oktay KESKiN ${ }^{1 *}$, Akın YiĞíN ${ }^{2}$, Osman Yaşar TEL ${ }^{1}$ \\ ${ }^{1}$ Harran Üniversitesi Veteriner Fakültesi Mikrobiyoloji Anabilim Dalı Eyyübiye, Şanlıurfa, Türkiye. \\ ${ }^{2}$ Harran Üniversitesi Veteriner Fakültesi Genetik Anabilim Dalı Eyyübiye, Şanlıurfa, Türkiye.
}

Geliş Tarihi: $\mathbf{2 4 . 0 2 . 2 0 1 8}$

Kabul Tarihi: 07.06.2018

Özet: $Q$ fever dünyanın birçok ülkesinde görülen önemli zoonotik infeksiyonlardan biridir. Etkenin kültürünün zor ve uzun zaman alıcı olmasının yanında Biyogüvenlik seviyesi-3 (Biosafety level-3) BSL-3 koşullarında gerçekleştirilmesi gerekliliği, hastalığın teşhisinin geniş oranda moleküler ve serolojik olmasını sağlamıştır. Bu çalışmada, ruminantlarda abortusa neden olan bu önemli patojenin rutin teşhiste Real-Time PCR ile hızlı ve doğru bir şekilde saptanması ve Şanlıurfa yöresinde hastalığın varlığının belirlenmesi amaçlandı. Çalışmada Harran Üniversitesi Veteriner Fakültesi Mikrobiyoloji Anabilim Dalına teşhis amaçlı getirilmiş olan ve -80 ㄷ'de saklanan toplam 202 adet sığır, keçi ve koyun atık materyali ve çalışma döneminde gelen 25 atık materyali Real-Time PCR tekniği ile incelendi. Bu amaçla içinde pozitif kontrol içeren Coxiella burnetii RealTime PCR kiti kullanıldı. Ayrıca test edilen C. burnetii suşları arasında son derece korumalı bir bölge olan C. burnetii com 1 geninin74-bp lik bir fragmentini amplifiye eden primer çiftleri kullanılarak klasik PCR yapıldı ve elde edilen amplikonlar agaroz jelde görüntülendi. Çalışmada incelenen toplam 227 adet atık materyalinden 4 adedi $(\% 1,8)$ hem Real-Time PCR hem de klasik PCR ile pozitif bulundu. Çalışmanın sonucunda önemli bir zoonoz olan bu ajanın hızlı ve güvenli bir şekilde tespit edilebildiği ve gerekli kontrol önlemlerinin alınmasına katkıda bulunacağı kanaatine varıldı.

Anahtar Kelimeler: Abort, Coxiella burnetii, Keçi, Koyun, Ruminant, Sı̆̆ır.

\section{Investigation of Coxiella burnetii by Real-Time PCR in Ruminant Abortus Cases}

Abstract: $Q$ fever is one of the important zoonotic infections which is seen in many parts of the world. Because the isolation of the agent is difficult and time consuming as well as the isolation and identification of the agent requires to be done under biosafety level-3 (BSL-3) conditions, the diagnosis of the disease is largely based on molecular and serological techniques. The aim of this study was to detect Coxiella burnetii accurately and quickly for routine diagnosis of the disease from the clinical samples by using real time PCR and to detect the presence of the $C$. burnetii in Şanlıurfa District. A total of 202 abortus materials kept at $-80^{\circ} \mathrm{C}$ and previously brought to Harran University Faculty of Veterinary Medicine Department of Microbiology for diagnosis and 25 aborted materials brought to our lab during this study period were tested by RealTime PCR. For Real-Time PCR analysis, a commercial C. burnetii Real-Time PCR kit was used including positive controls. Besides, a classical PCR was performed by using a pair of primers which amplifies a 74-bp fragment of the com 1 gene of $C$. burnetii, which is highly conserved region in the genom of agent and amplicons were visualized in the $4 \%$ agarose gel. Four out of 227 test samples (1.8\%) samples were found positive by both Real-Time and classical PCR test. In the end of the study, it was concluded that this important zoonotic agent could be determined fast and reliable and contribute to take necessary preventive measures on time.

Keywords: Abortus, Cattle, Coxiella burnetii, Ewe, Goat, Ruminants.

\section{Giriş}

Ruminantlarda önemli kayıplara neden olan abortuslar oldukça kompleks bir etiyolojiye sahiptir ve tanıları uzun ve zorlu bir süreci gerektirebilir. $Q$ humması (Q-fever) etkeni olan C. burnetii de ruminantlarda atıklara neden olan başlıca etkenler arasındadır ve zoonoz olması açısından da önemlidir (Marrie, 1990). Hastalık bugün için Yeni Zelanda ve Antarktika hariç hemen hemen bütün Dünya'da yaygın olarak gözlenmektedir (Arricau-Bouvery ve ark., 2006; Kennerman ve ark., 2010). Uluslararası Salgın Hastalıklar Ofisi'nin (OIE) hastalıklar listesinde yer almasına rağmen, bugüne kadar Türkiye'de sadece araştırma düzeyinde ve genellikle serolojik testlerle var olduğu bildirilen $Q$ fever infeksiyonu, 5996 sayılı “Veteriner Hizmetleri, Bitki Sağlığı, Gıda ve Yem Kanunu"nda yer almadı̆̆ı gibi, inbari mecburi hastalıklar listesinde de yoktur. Dolayısıyla bugüne kadar infeksiyonun korunma ve kontrolü ile ilgili herhangi bir prosedür ya da politika belirlenmemiştir. C. burnetii'nin başlıca kaynağı evcil ruminantların atık ile yarattıkları çevre kontaminasyonlarıdır. Etken memeliler, kuşlar ve artropodlar gibi oldukça geniş bir konakçı spektrumuna sahiptir. (Kılıç ve ark., 2008; Lee ve ark., 2004, OIE, 2015). Bu infeksiyonun tanısının yapılması, tedavinin bir an önce başlatılmasının 
yanında aşılama, dezenfeksiyon karantina gibi her türlü koruma ve kontrol tedbirlerinin alınması açısından da oldukça önemlidir. Ancak zorunlu hücre içi patojeni olan bu bakterinin normal besi yerlerinde ürememesi, üremek için hücre kültürü, embriyolu tavuk yumurtası gibi canlı ortamlara intiyaç duyması izolasyonunu sınırlamaktadır (Nicollet ve Valognesi, 2007; OIE, 2015). Daha da önemlisi, infektivitesi yüksek bir zoonoz olması nedeni ile BSL-3 kabinlerde çalışılması zorunludur. Bütün bu dezavantajlardan dolayı $C$. burnetii'nin neden olduğu $Q$ fever'ın laboratuvar tanısı, zahmetli ve zaman alan bir süreçtir. Bu nedenle Türkiye'de bugüne kadar $C$. burnetii'den kaynaklanan atık vakalarının teşhisi çalışmaları sadece lokal olarak yapılan serolojik ve az sayıda moleküler testlerin kullanıldığı araştırmalar ile sınırlı kalmıştır. Türkiye'de hastalığın varlığı ise ilk kez Payzın ve ark. (1953) tarafından bildirilmiştir. Daha sonra ise serolojik olarak (Berberoğlu ve ark., 2004; Çetinkaya ve ark., 2000; Günaydın ve Pekkaya, 2016; Kennerman ve ark., 2010; Özgür ve ark., 1997) ve moleküler (Can ve ark., 2015; Kılıç ve ark., 2016; Kırkan ve ark., 2008; Özkaraca ve ark., 2016; Parın ve Kaya, 2015) yöntemlerle hayvanlarda, ve serolojik olarak riskli gruplarda bulunan insanlarda (Arserim ve ark., 2011; Çetinkaya ve ark., 2000; Özgür ve ark., 1996; Seyitoğlu ve ark., 2006) hastalığın tespiti ile ilgili pek çok araştırma yapılmıştır.

C. burnetii infeksiyonlarının tanısının hızlı ve doğru bir şekilde yapılmasının sağlanması, zoonoz olan bu infeksiyon için erken uyarı yapılmasını sağlayacağı gibi, kontrol önlemlerinin de gerektiği gibi alınmasını sağlayacaktır. Bu araştırmada, $C$. burnetii'nin atık yavru dokularından Real-Time PCR tekniği ile tespitinin yapılarak $Q$ fever infeksiyonun teşhisi için rutin olarak kullanımının sağlanması ve bölgemizde hastalığının ne oranda mevcut olduğunun araştırılması amaçlanmıştır.

\section{Materyal ve Metot}

Atık yavru doku ve organ örnekleri: Çalışmada Harran Üniversitesi Veteriner Fakültesi Mikrobiyoloji Anabilim Dalı'na daha önceki yıllarda teşhis amaçlı getirilmiş olan ve -80 ㅇ' ${ }^{\prime}$ de muhafaza edilen 202 adet sığır, keçi ve koyun atık materyalleri (her bir vakaya göre değişmek üzere plasenta, vaginal svab, cenin mide sıvısı ve iç organlarından biri ya da birkaçı ya da tümünden hazırlanan homojenatlar) ve çalışma döneminde gelen 25 atık materyali olmak üzere toplam 227 adet atık materyali kullanıldı.

Doku ve Svab Örneklerinden DNA İzolasyonu: DNA ekstraksiyonu amacıyla High Pure PCR template
DNA ekstraksiyon kiti üretici firmanın prospektüsüne uygun olarak kullanıldı (Roche Katolog no: 11796828001). İzole edilen DNA'lar -20 ${ }^{\circ} \mathrm{C}$ de PCR yapılıncaya kadar saklandı.

DNA miktarının Belirlenmesi: DNA miktarı spektrofotometrede (NanoDrop ND-2000) ile 260 ve $280 \mathrm{~nm}$ de ölçülerek belirlendi. Ortalama 227 örnek için total bakteri DNA konsantrasyonu 112,3 $\pm 0,3$ $\mathrm{ng} / \mu \mathrm{L}$ olarak tespit edildi.

Sayısal Real Time PCR Analizleri: Real Time PCR analizlerinde içinde internal pozitif kontrol içeren Coxiella brunetii Real-Time PCR kiti (Primerdesign Ltd Coxiella burnetii DNA Gyrase Subunit A Genesig ${ }^{\circledR}$ Standard kit) kullanıldı. Real-Time PCR işlemi Qiagen Rotorgene cihazı kullanılarak gerçekleştirildi. Her bir örnek için qPCR master miksten $10 \mu \mathrm{L}, C$. burnetii primer/probe miksinden 1 $\mu \mathrm{L}$, internal ekstraksiyon kontrol primer/probe miksinden $1 \mu \mathrm{L}$, internal kontrol DNA'dan 0,5 $\mu \mathrm{L}$, RNAse/DNAse free PCR grade distile sudan $2.5 \mu \mathrm{L}$ olmak üzere toplamda $15 \mu \mathrm{L}$ PCR miks hazırlandı ve her bir tüpe koyularak üzerine $5 \mu \mathrm{L}$ izolasyon yapılmış DNA'lar eklendi.

Sonuçlar değerlendirilirken Real-Time PCR cihazının Green kanalı (FAM probe) örnekler, yellow kanalı da (VIC probe) internal kontrol (IC) için kullanılmıştır. Kit prosedüründe de ayrıntılı olarak anlatıldığı şekilde her pozitif olan her örnek için iki amplifikasyon eğrisi alındı. Negatif olan örnekler de sadece IC kanalında sonuçlar alındı. Eğer bir örnekte IC eğrisi yoksa örneğin çalışmadığı düşünülerek tekrar çalışmaya alındı. Ayrıca pozitif olduğu tespit edilen örnekler tekrarlı olarak çalışıldı.

Bunun dışında ayrıca $C$. burnetii suşları arasında son derece korumalı bir bölge olan C.burnetii com 1 geninin 74-bp lik bir fragmentini amplifiye eden primer çiftleri (Brennan ve Samuel, 2003) (FAF216 5'-GCACTATTTTTAGCCGGAACCTT-3' ve RAF290 '-TTGAGGAGAAAAACTGGATTGAGA-3') kullanılarak klasik PCR yapıldı ve elde edilen amplikonlar UV ışık altında $\% \quad 4$ lük jelde görüntülendi.

\section{Bulgular}

Çalışmada 227 atık örneğinden izole edilen DNA'lar Real-Time PCR ve konvansiyonel PCR ile test edildiklerinde 4 örnek $(\% 1,8)$ Real-Time PCR ve com1 geni hedef alınan konvansiyonel PCR'da pozitif bulundu. Her iki yöntemde pozitif bulunan örnekler aynı örnekler oldu. Çalışmada 132 sığır örneğinden gelen DNA örneklerinde pozitiflik oranı $\% 1,5$ iken, 72 koyun örneğinde $\% 2,7$ olarak belirlendi (Tablo 1). 
Tablo 1. Q fever yönünden Real-Time PCR ile test edilen örneklerin hayvan türlerine ve toplam hayvan sayısına göre pozitiflik oranları.

\begin{tabular}{lccccc}
\hline \multirow{2}{*}{ Hayvan türü } & $\begin{array}{c}\text { Test edilen } \\
\text { hayvan sayısı }\end{array}$ & \multicolumn{2}{c}{ Real-time PCR test sonucu } & \multicolumn{2}{c|}{ Konvansiyonel PCR sonucu } \\
\cline { 2 - 6 } & 132 & $\mathbf{n}$ & $\mathbf{\%}$ & $\mathbf{n}$ & $\mathbf{\%}$ \\
\hline Sı̆̆ır & 72 & 2 & 1,5 & 2 & 1.5 \\
Koyun & 23 & 2 & 2,7 & 2 & 2,7 \\
Keçi & $\mathbf{2 2 7}$ & - & & - & \\
Toplam & & $\mathbf{4}$ & $\mathbf{1 , 8}$ & $\mathbf{4}$ & $\mathbf{1 , 8}$ \\
\hline
\end{tabular}

Real-Time PCR: Çalışmada pozitif bulunan 3, 28, 80 numaralı pozitif örneklerin tekrarlanan sonuçlarının amplifikasyon eğrileri Şekil 1. de gösterilmektedir.
Çalışılan standartlar ve 163 numaralı pozitif örneğin sonuç amplifikasyon eğrileri ise Şekil 2. de gösterilmektedir.
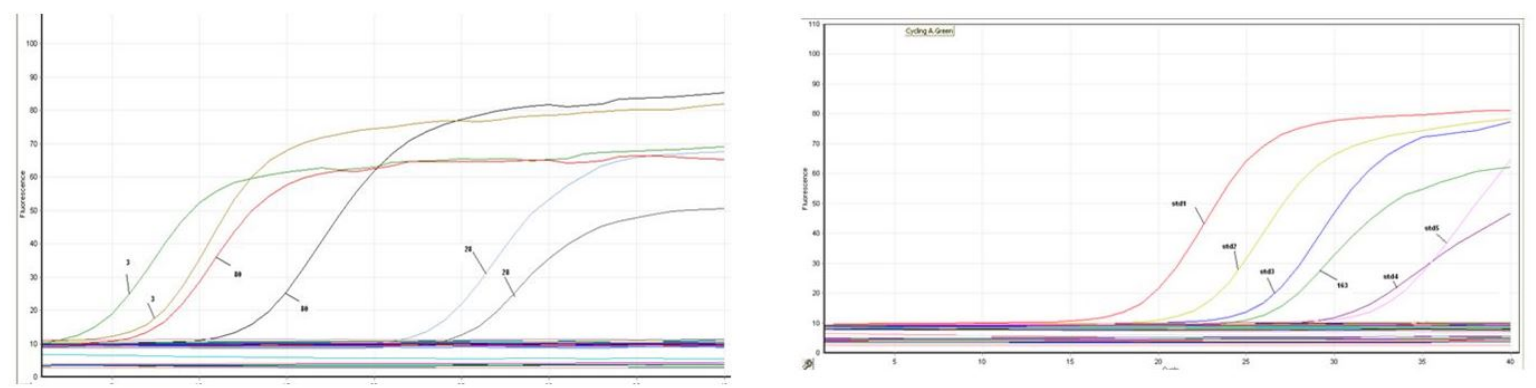

Şekil 2. Çalışılan standartlar ve 163 numaralı pozitif örneğin sonuç amplifikasyon eğrileri.

Konvansiyonel PCR: Tüm C. burnetii suşlarında korumalı bir bölge olan com 1 geninin 74-bp lik bir fragmentiniamplifiye eden primer çiftlerinin kullanıldı̆ı PCR'da da, Real-Time PCR'da pozitif bulunan 3, 28, 80 ve 163 nolu örnekler pozitif bulundu (Şekil 3). Kuyucuk1-4: 3, 28, 80, 163 nolu pozitif örnek amplikonları; kuyucuk 5: Negatif kontrol; Kuyucuk 6-9; Pozitif örnek DNA'larının $1 / 10$ dilüsyonundan yapılan PCR amplikonları; Kuyucuk 10: Negatif kontrol; Kuyucuk 12: Pozitif kontrol (74 bp'lik amplikon); Kuyucuk 13: Pozitif kontrol (1/10 DNA dilüsyonu); Kuyucuk 14: DNA Ladder.

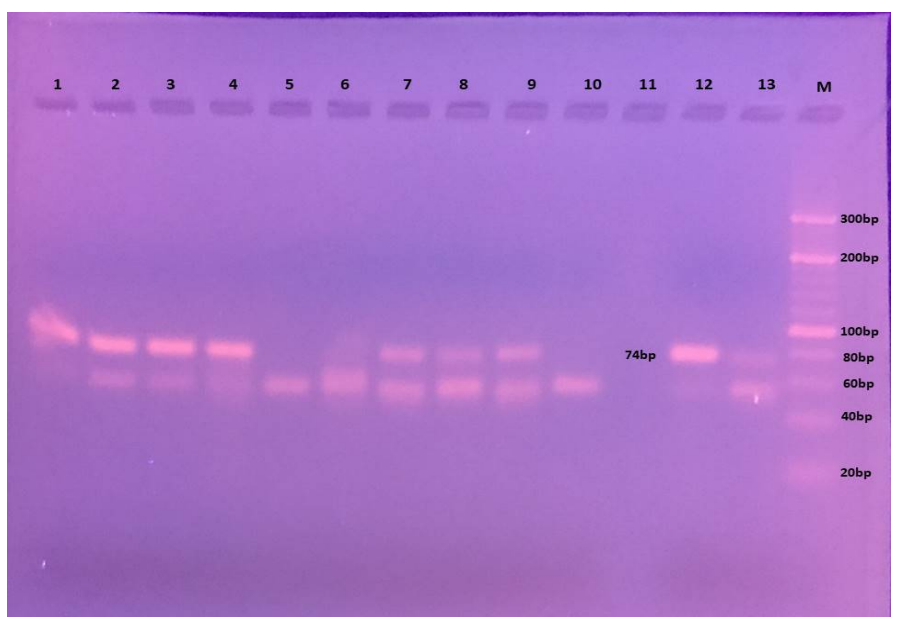

Şekil 3. Pozitif örneklerin ve standartların amplikonlarının agaroz jelde görüntülenmesi Kuyucuk1-4: 3,28,80,163 nolu pozitif örnek amplikonları; kuyucuk 5: Negatif kontrol; Kuyucuk 6-9; Pozitif örnek DNA'larının 1/10 dilüsyonundan yapılan PCR amplikonları; Kuyucuk 10: Negatif kontrol; Kuyucuk 12: Pozitif kontrol (74 bp'lik amplikon); Kuyucuk 13: Pozitif kontrol (1/10 DNA dilüsyonu); Kuyucuk 14: DNA Ladder. 


\section{Tartışma ve Sonuç}

Zorunlu bir hücre içi paraziti olan Coxiella burnetii tarafından oluşturulan $\mathrm{Q}$ fever hem hayvan hem de insanlarda infeksiyona neden olan ve neredeyse dünyanın her yerinde görülen önemli bir zoonozdur (Marrie, 1990). Hastalığın teşhisinde etkenin izolasyonu altın standart olmakla birlikte, izolasyon sürecinin zor, uzun, ve riskli olması nedeni ile teşhis büyük ölçüde seroloji ve moleküler testlere dayanmaktadır (Nicolett ve Valognes, 2007; OIE, 2015; Sidi-Boumedine ve Rousset, 2011, SidiBoumedine ve ark., 2010).

$\mathrm{Bu}$ çalışmada, ruminant abortlarında $C$. burnetii'nin varlığı Real-Time PCR ile saptanarak, infeksiyonun bölgemizdeki pozitiflik oranı araştırıldı. $Q$ fever infeksiyonunun teşhisi için ülkemizin farklı bölgelerinde bazı moleküler çalışmalar yapılmıştır. $\mathrm{Bu}$ çalışmalarda etkenin farklı genetik bölgeleri için dizayn edilmiş primerler kullanılarak çeşitli PCR teknikleri uygulanmış ve infeksiyonun pozitiflik oranı saptanmıştır. Kılıç ve ark. (2016), Türkiye'nin doğusunda koyun abortlarında yaptıkları bir çalışmada Trans-PCR ile pozitiflik oranını \%2, embriyolu tavuk yumurtasından etken izolasyon oranını \%2,5 olarak saptamışlardır. Çalışmamızda 227 atık örneğinden Real-Time PCR ile pozitif örnek sayısı 4 olarak tespit edilerek pozitiflik oranı \%1,8 olarak saptandı. Bu pozitiflik oranı Kılıç ve ark. (2016)'nın sonuçları ile çok yakın bulunmuştur. Can ve ark. (2015), Hatay yöresinde inek, keçi ve koyun süt tanklarından aldıkları toplam 150 örnekten yaptıkları PCR ile pozitiflik oranını \% 6 olarak bulmuşlardır. Buldukları dokuz pozitif örneğin dağılımını sığırlarda beş, koyunlarda iki ve keçilerde iki olarak saptamışlardır. Çalışmamızda ise sığır örneklerinde pozitiflik oranı \%1,5 iken koyun örneklerinde \%2,7 olarak bulunarak araştırıcıların bulguları ile türlerin pozitifliği açısından farklılık göstermiştir. Kırkan ve ark. (2008) toplam 138 sığır kan örneğine yaptıkları Trans PCR ile pozitiflik yüzdesini \%4,3 olarak saptamışlardır. Özkaraca ve ark. (2016) 70 sığır fötüsünde yapmış oldukları PCR, IHC ve kültür ile pozitiflik yüzdesini $\% 1,42$ olarak bulmuşlardır. Hastalığın serolojik olarak pozitiflik oranları çeşitli araştırıcılar tarafından yapılan moleküler testlere oranla çok daha yüksek bulunmuştur (Arserim ve ark., 2011; Gülmez Sağlam ve Şahin, 2016; Kalender, 2001; Parın ve Kaya, 2015). Gülmez Sağlam ve ark. (2016) Kars yöresinde 350 sığır ve 250 koyun süt örneğine yaptıkları PCR sonucu beş $(\% 1,42)$ sığır ve bir koyun $(\% 0,4)$ örneğinde pozitiflik saptamışlardır. Oysa aynı çalışmada ELISA ile koyunlarda pozitiflik oranı $\% 43,2$ ve sığırlarda $\% 14,8$ olarak bulunmuştur. Bunun nedeni serolojik testlerin genelde sürü tarama testleri olmasından ve yanlış pozitifliklerin bir hayli fazla olmasından kaynaklanabilir. Yapılan literatür taramasına göre, ülkemizde hastalığın ruminantlarda PCR ile teşhisine yönelik yapılan çok sınırlı sayıda araştırmada, pozitiflik oranının \% 0,4-6 aralığında değiştiği anlaşılmaktadır. Çalışmamızda saptamış olduğumuz pozitiflik oranı $(\% 1,8)$ bu aralıkta bulunmakta ve diğer araştırıcıların bulguları ile benzerlik göstermektedir.

Sonuç olarak, Real-Time PCR ile ruminant atıklarında bölgemizde sığırlarda $\% 1,5$ ve koyunlarda \%2,7 oranında pozitiflik saptanmış ve hastalığın bölgemizde varlığı ortaya konulmuştur. Ayrıca, zoonotik bir ajan olan C. burnetii'nin yayılmasını sınırlamaya indirekt yardımc olabilecek moleküler bir teknik olan Real-Time PCR tekniğinin, hastalığın rutin teşhisinde kullanılabilecek güvenilir bir test olduğu sonucuna varılmıştır.

\section{Teşekkür}

Bu çalışma, HÜBAK tarafından 16069 proje numarası ile desteklenmiştir.

\section{Kaynaklar}

Arricau-Bouvery N, Hauck $Y$, Bejaoui A, Frangoilidis D, Bodier C.C, Souriau A, Meyer H, Neubauer H, Rodolakis A, Vergnaud G, 2006: Molecular characterization of Coxiella burnetii isolates by infrequent restriction site-PCR and MLVA typing. BMC Microbiology, 6, 38.

Arserim NB, Yeşilmen S, Özekinci T, Tel OY, Keskin O, Pulat H, Vural A, 2011: Seroprevalance of Coxiellosis in cows, sheep, goats and humans in Diyarbakir region of Turkey. Afr J Microbiol Res, 5, 2041-2043.

Berberoğlu U, Gözalan A, Kiliç S, Kurtoğlu D, Esen B, 2004: A seroprevalence study of Coxiella burnetii in Antalya, Diyarbakır and Samsun provinces. Mikrobiyol Bul, 38, 385-391.

Brennan RE, Samuel JE, 2003: Evaluation of Coxiella burnetii Antibiotic Susceptibilities by Real-Time PCR Assay. J Clin Microbiol, 41, 1869-1874.

Can HY, Elmalı M, Karagöz A, 2015: Detection of Coxiella burnetii in cows', goats', and ewes' bulk milk samples using polymerase chain reaction (PCR). Mljekarstvo, 65, 26-31.

Çetinkaya B, Kalender H, Ertas HB, Muz A, Arslan N, Ongor $H$, Gurçay M, 2000: Seroprevalence of coxiellosis in cattle, sheep and people in the east of Turkey. Vet Rec, 146, 131-136.

Gülmez Sağlam A, Şahin M, 2016: Coxiella burnetii in samples from cattle herds and sheep flocks in the Kars region of Turkey. Vet Med, 61, 17-22.

Günaydın E, Pekkaya S, 2016: Serologic and molecular investigation of $Q$ Fever on water buffalo in Afyon. Van Vet J, 27, 17-19.

Kalender H, 2001:Elazığ ve komşu illerdeki koyunlarda Coxiella burnetii enfeksiyonunun yaygınlığı. Turk $J$ Vet Anim Sci, 25, 51-55.

Kennerman E, Rousset E, Gölcü E, Dufour P, 2010: Seroprevalance of $Q$ fever (coxiellosis) in sheep from 
the Southern Marmara Region, Turkey. Comp Immunol Microbiol Infect Dis, 33, 37-45.

Kılıç A, Kalender H, Koç O, Kılınç Ü, Irehan B, Berri M, 2016: Molecular investigation of Coxiella burnetii infections in aborted sheep in Eastern Turkey. IJVR, 17(1), 41-44, (2016).

Kılıç S, Komiya T, Çelebi B, Aydın N, Saito J, Toriniwa H, Karatepe B, Babür C, 2008: Seroprevelance of Coxiella burnetii in Stray Cats in Central Anatolia. Turk J Vet Anim Sci, 32, 483-486.

Kırkan Ş, Kaya O, Tekbıyık S, Parın U, 2008: Detection of Coxiella burnetii in cattle by PCR. Turk $J$ Vet Anim Sci, 32, 215-220.

Lee JH, Park HS, Jang WJ, Koh SE, Park TK, Kang SS, Kim BJ, Kook YH, Park KH, Lee SH, 2004: Identification of the Coxiella sp. detected from Haemaphysalis longicornis Ticks in Korea. Microbiol Immunol, 48, 125-130.

Marrie TJ, 1990: Q fever-a review. Can Vet J, 33, 555-563.

Nicollet $P$, Valognes A, 2007: Current review of $Q$ fever diagnosis in animals. Bull Acad Vét France, 160: 289295.

OIE, 2015: Q Fever, Chapter 2.1.16.World Organization for Animal health, Manual of diagnostic test and vaccines for terrestrial animals

Özgür NY, Hasöksüz M, Yılmaz H, íkiz S, Ilgaz A, 1996: Risk grubundaki insanlarda Coxiella burnetii antikorlarının araştırılması. Türk Mikrobiyol Der, 26, 109-113.

Özgür NY, Hasöksüz M, Yılmaz H, İkiz S, Ilgaz A, 1997: Infertilite sorunu olan dişi sığırlarda ve insanlarda Coxiella burnetii antikorlarının ELISA testi ile belirlenmesi ve sero-prevalansın saptanması, Pendik Vet Mikrobiyol Derg, 2, 207-218,

Özkaraca $M$, Çeribaşı $S$, Çeribaşı AO, Kılıç A, Altun $S$, Çomaklı S, Öngör H, 2016: Determination of Coxiella burnetii in bovine foetuses using PCR and immunohistochemistry. Vet Med, 61, 421-427.

Parın U, Kaya O, 2015: Detection of Coxiella burnetii Prevalence in bovine, ovine and caprine herds. Ankara Üniv Vet Fak Derg, 62, 177-181.

Payzın S, 1953: Epidemiological investigations on Q Fever in Turkey. Bull World HIth Org, 9, 553-558.

Seyitoglu Ş, Özkurt Z, Dinler U, Okumuş B, 2006: The seroprevalence of Coxiellosis in farmers and cattle in Erzurum district in Turkey. Turk J Vet Anim Sci, 30, 71-75.

Sidi-Boumedine K, Rousset E, 2011: Molecular epidemiology of $Q$ fever: a review of Coxiella burnetii genotyping methods and main achievements. Euroreference 5: 30-38.

Sidi-Boumedine $K$, Rousset ., Henning, Ziller $M$, Niemczuck K, Roest HIJ, Thiery R, 2010: Development of harmonized schemes for monitoring and reporting $Q$ - fever in animals in European Union, EFSA scientific report. EFSA-Q2009-00511.

*Yazışma Adresi: Oktay Keskin

Harran Üniversitesi Veteriner Fakültesi Mikrobiyoloj

iAnabilim Dalı Eyyübiye, Şanlıurfa, Türkiye.

e-mail: okeskin@harran.edu.tr 